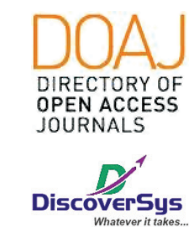

Published by DiscoverSys

\section{Korelasi kadar leptin serum terhadap derajat penyakit dermatitis atopik}

\author{
Gde Ngurah Arya Ariwangsa,${ }^{1 *}$ Made Wardhana, ${ }^{2}$ Luh Made Mas Rusyati ${ }^{2}$
}

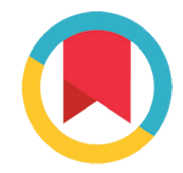

CrossMark

\title{
ABSTRACT
}

Background: Atopic dermatitis (AD) is a chronic and residual skin inflammatory disease in which the symptoms include intense itching, chronic exacerbations and remissions, with multifactorial etiologies. The role of leptin in DA is closely related to polarization of T cells towards Th1 cells resulting in the release of pro-inflammatory cytokines.

Methods: A cross-sectional study was conducted among 30 atopic dermatitis patients at Sanglah General Hospital in the period of July-August 2018. The leptin examination was carried out using the ELISA method. Data analysis were performed using SPSS version 25.0 software with the Spearman correlation test to determine the relationship between levels of serum leptin and the severity of atopic dermatitis based on SCORAD.

Results: Most of the respondents were females (66.7\%) with an average leptin level was $25.75+18.21 \mathrm{pg} / \mathrm{dL}$. The results showed a significant negative correlation between the level of serum leptin and the severity of DA (SCORAD) (r: $-0.127 ; \mathrm{p}: 0.043)$. However, there was a significant positive correlation between $\mathrm{pH}$ of the skin and SCORAD ( $\mathrm{r}: 0.810$ and $\mathrm{p}:<0.001$ ).

Conclusions: There is a negative correlation between level of serum leptin and SCORAD but it has a strong positive correlation between the $\mathrm{pH}$ of the skin and SCORAD.
1Program Pendidikan Dokter Spesialis, Ilmu Penyakit Kulit dan Kelamin, RSUP Sanglah, Fakultas Kedokteran, Universitas Udayana, Bali, Indonesia

${ }^{2}$ Departemen Kulit dan Kelamin, RSUP Sanglah, Fakultas Kedokteran, Universitas Udayana, Bali, Indonesia

*Korespondensi: Gde Ngurah Arya Ariwangsa; Program Pendidikan Dokter Spesialis, IImu Penyakit Kulit dan Kelamin, RSUP Sanglah, Fakultas Kedokteran, Universitas Udayana, Bali, Indonesia aryaariwangsa@yahoo.co.id

Received: 2018-10-24

Accepted: 2018-12-02

Published: 2019-04-01

Keywords: Atopic dermatitis, leptin, SCORAD

Cite This Article: Ariwangsa, G.N.A., Wardhana, M., Rusyati, L.M.M. 2019. Korelasi kadar leptin serum terhadap derajat penyakit dermatitis atopik. Intisari Sains Medis 10(1): 108-113. D0l: 10.1556/ism.v10i1.334

\section{ABSTRAK}

Latar Belakang: Dermatitis atopik (DA) adalah penyakit peradangan kulit yang bersifat menahun dan residif dimana gejalanya meliputi rasa gatal hebat, eksaserbasi kronik dan remisi, dengan etiologi yang sifatnya multifaktorial. Peranan leptin pada DA berhubungan erat dengan polarisasi sel T kearah sel Th1 sehingga menghasilkan pelepasan sitokin-sitokin pro inflamasi. Penelitian ini bertujuan untuk mengetahui peran leptin terhadap derajat penyakit DA.

Metode: Penelitian dengan desain potong lintang dilakukan terhadap 30 pasien dermatitis atopik di RSUP Sanglah dalam periode JuliAgustus 2018. Pemeriksaan leptin ini memakai metode ELISA. Analisis data memakai SPSS versi 25.0 dengan uji korelasi Spearman untuk mengetahui hubungan antara leptin serum dengan derajat keparahan dari dermatitis atopik berdasarkan SCORAD.

Hasil:Sebagian besar responden merupakan jenis kelamin perempuan $(66,7 \%)$ dengan kadar rata-rata leptin adalah $25,75+18,21 \mathrm{pg} / \mathrm{dL}$. Hasil penelitian menunjukkan korelasi negatif lemah bermakna antara kadar leptin serum dengan tingkat keparahan DA (SCORAD) (r:-0,127; p:0,043). Akan tetapi Didapatkan hasil korelasi positif kuat bermakna antara pH kulit dengan SCORAD ( $r: 0,810$ dan $p:<0,001)$.

Simpulan: Terdapat korelasi negatif antara kadar leptin serum dengan SCORAD namun memiliki korelasi positif kuat antara pH kulit dengan SCORAD.

Kata kunci: Dermatitis atopik, leptin, SCORAD

Cite Pasal Ini: Ariwangsa, G.N.A., Wardhana, M., Rusyati, L.M.M. 2019. Korelasi kadar leptin serum terhadap derajat penyakit dermatitis atopik. Intisari Sains Medis 10(1): 108-113. D0I: 10.1556/ism.v10i1.334

\section{PENDAHULUAN}

Dermatitis atopik (DA) merupakan penyakit inflamasi kulit yang sifatnya gatal, kemerahan dan kronis dimana hal ini berhubungan dengan peningkatan kadar serum IgE, gangguan fungsi sawar kulit, dan sensitisasi terhadap makanan dan alergen lingkungan. ${ }^{1,2}$ Pada stadium akut dermatitis atopik ini ditemukan erosi, edema, eritema dan vesikel. Stadium kronik ditandai oleh adanya proses likenifikasi. Dalam beberapa dekade terakhir, angka kejadian DA meningkat secara pesat hingga menjadi salah satu masalah kesehatan di dunia. ${ }^{3}$

Prevalensi DA secara global dilaporkan meningkat drastis dalam 30 tahun terakhir. ${ }^{4}$ Sedangkan prevalensi DA di Indonesia termasuk lima besar penyakit kulit yang sering dijumpai. ${ }^{5}$ Belum ditemukan penyebab pasti DA. Berbagai faktor yang 
kemungkinan berperan dalam patogenesis dermatitis atopik antara lain faktor genetik, lingkungan, sawar kulit, dan sistem kekebalan. ${ }^{3}$

Sel T pada DA sangatlah penting, terjadi gangguan keseimbangan sel $\mathrm{T}$ dalam hal ini Th 1 dan Th 2 selanjutnya menyebabkan produksi interleukin IL 4, IL 5, IL 13 meningkat yang menyebabkan peningkatan level IgE dan eosinofil serta menginduksi molekul adesi yang terlibat pada migrasi sel inflamasi ke kulit dimana epidermis mengalami kerusakan. Salah satu penyebab ketidak seimbangan Th1 dan Th2 diduga dipengaruhi oleh leptin. ${ }^{3}$

Leptin adalah hormon protein proinflamasi yang diproduksi oleh adiposit sedangkan peranan adiposit dikatakan masih belum jelas dalam penyakit alergi. Mekanisme kerja leptin ini ada 2 yaitu secara perifer dikatakan dapat merangsang proliferasi dan diferensiasi sel-sel keratinosit dan fibroblast, sedangkan secara sentral yaitu untuk meningkatkan pembakaran kalori dengan cara peningkatan aktivitas tubuh dan menekan nafsu makan. ${ }^{6}$ Leptin memiliki jumlah sekitar 5-15 ng/mL yang bersirkulasi dalam darah. Leptin mempunyai konsentrasi tinggi pada sore hari dan pagi hari, hal tersebut dikarenakan leptin disekresikan secara berkala dan mempunyai variasi diurnal. Leptin pada sistem imunitas mempunyai sejumlah efek proinflamasi, seperti proliferasi dan aktivasi monosit pada sirkulasi, polarisasi sel $\mathrm{T}$ melalui respon sel Th1, sel T CD4 dan CD8, kemotaksis netrofil serta upregulasi sejumlah sitokin termasuk TNF- $\alpha$, IL-6, IFN- $\gamma$ dan IL-2, serta perkembangan dan aktivasi sel NK. ${ }^{6,7}$

Pada anak-anak obesitas telah dilakukan penelitian bagaimana leptin berperan pada DA. Pada anak obesitas, manifestasi dermatitis atopik berhubungan dengan keadaan hiperleptinemia, yaitu produksi leptin berlebih karena gangguan sinyal leptin pada reseptor leptin maupun resistensi leptin. Leptin meningkatkan sekresi sitokin proinflamasi seperti TNF- $\alpha$, IL-6 dan IL-12. ${ }^{8}$ Peranan sel $\mathrm{T}$ pada patogenesis dermatitis atopik sangat penting. Sel T helper (Th) terdiri dari Th1 dan Th2. Sel Th1 akan memproduksi sitokin IFN- $\gamma$, TNF-a, IL 2, IL-6, IL-9, sedangkan Th2 akan memproduksi sitokin IL4, IL-5, IL-10, dan IL-13. Peningkatan leptin akan mengakibatkan ketidakseimbangan sel T, sehingga mengakibatkan terjadi DA. ${ }^{9}$ IL-4, IL-5 dan IL-13 menyebabkan peningkatan level IgE dan eosinofil serta menginduksi molekul adesi yang terlibat pada migrasi sel inflamasi ke lesi kulit sehingga epidermis mengalami kerusakan maka timbul manifestasi DA. ${ }^{2}$

Beberapa penelitian terdapat kontroversi, ada penelitian oleh Mohamed dkk yang meneliti kadar leptin yang tinggi pada dermatitis atopik tanpa disertai obesitas. ${ }^{10}$ Sebaliknya penelitian oleh Seo dkk tidak menemukan hubungan signifikan antara kadar leptin dengan dermatitis atopik. ${ }^{11}$ Berkaitan dengan adanya perbedaan antara hasil penelitian terdahulu maka studi ini bertujuan untuk menentukan peran leptin terhadap derajat penyakit dermatitis atopik

\section{METODE}

Penelitian ini menggunakan desain potong lintang terhadap 30 pasien dermatitis atopik yang telah memenuhi kriteria inklusi dan eksklusi Poliklinik Kulit dan Kelamin RSUP Sanglah Denpasar dalam periode 1 Juli -31 Agustus 2018. Kriteria inklusi penelitian adalah Pasien DA yang memenuhi kriteria diagnosis DA menurut hanifin dan rajka secara anamnesis dan pemeriksaan klinis, yang berkunjung ke Poliklinik Kulit dan Kelamin RSUP Sanglah Denpasar, pasien warga negara Indonesia, berusia 18 - 70 tahun dengan jenis kelamin lakilaki ataupun perempuan, keadaan umum baik, dan bersedia untuk diikutsertakan dalam penelitian serta menandatangani lembar informed consent. Kriteria eklusi adalah pasien sedang menderita penyakit peradangan kronis pada kulit, pasien yang sedang menderita infeksi kulit maupun sistemik, pasien yang memiliki penyakit metabolik, pasien yang memiliki riwayat penyakit jantung dan pasien yang sedang mengkonsumsi glukokortikoid.

Teknik pengumpulan data dilakukan dengan wawancara, pemeriksaan fisik, dan pengambilan sampel darah. Kuesioner wawancara dipergunakan untuk mendapatkan data demografis subyek penelitian. Pemeriksaan fisik dilakukan secara lengkap disertai pemeriksaan status dermatologis. Pemeriksaan kadar leptin dilakukan melalui pemeriksaan ELISA yang dikur dalam satuan pg/dL. Data kemudian dianalisis menggunakan piranti lunak SPSS version 16 untuk mengetahui persentase, rata-rata \pm simpang baku (SB), maupun nilai korelasinya. Sebelum dilakukan analisis univariat dan bivariat, uji normalitas data dilakHasil penelitian dikatakan bermakna apabila nilai $\mathrm{P}$ diperoleh dibawah 0.05 .

\section{HASIL}

Berdasarkan penelitian yang telah dilakukan terhadap 30 responden dari variabel yang digunakan dalam penelitian ini ditemukan bahwa, rerata usia pasien adalah 43,83+17,87 tahun. Berdasarkan distribusi jenis kelamin pada subjek DA, didapatkan sebanyak 20 orang $(66,7 \%)$ berjenis kelamin perempuan dan 10 orang $(33,3 \%)$ berjenis kelamin laki-laki. (Tabel 1).

Penelitian ini dilakukan uji normalitas menggunakan uji analisis Shapiro-Wilk karena jumlah 
Tabel 1 Gambaran karakteristik subjek penelitian

\begin{tabular}{|c|c|c|}
\hline Karakteristik & Rerata + SB & N (\%) \\
\hline Usia (Tahun) & $43,83+17,87$ & \\
\hline \multicolumn{3}{|l|}{ Jenis Kelamin } \\
\hline Laki-laki & & $10(33,3)$ \\
\hline Perempuan & & $20(66,7)$ \\
\hline Kadar Leptin (pg/dL) & $25,75+18,21$ & \\
\hline \multicolumn{3}{|l|}{ Tingkat Keparahan (SCORAD) } \\
\hline Ringan & & $3(10 \%)$ \\
\hline Sedang & & $10(33,3 \%)$ \\
\hline Berat & & $17(56,7 \%)$ \\
\hline Kadar $\mathrm{pH}$ & $6,51+0,65$ & \\
\hline \multicolumn{3}{|l|}{ Pekerjaan } \\
\hline Guru & & $1(3.3 \%)$ \\
\hline Ibu Rumah Tangga & & $2(6.7 \%)$ \\
\hline Mahasiswa & & $2(6.7 \%)$ \\
\hline Pensiunan PNS & & $2(6.7 \%)$ \\
\hline Petani & & $2(6.7 \%)$ \\
\hline PNS & & $3(10 \%)$ \\
\hline Tenaga Medis & & $10(33.3 \%)$ \\
\hline Tidak Bekerja & & $1(3.3 \%)$ \\
\hline Wiraswasta & & $7(23.3 \%)$ \\
\hline \multicolumn{3}{|l|}{ Riwayat Atopik pada Keluarga } \\
\hline Ada Riwayat Atopik & & $23(76.7 \%)$ \\
\hline Tidak Ada Riwayat Atopik & & $7(23.3 \%)$ \\
\hline Tinggi Badan (cm) & $160.80 \pm 5.55$ & \\
\hline Berat Badan $(\mathrm{cm})$ & $59.63 \pm 6.12$ & \\
\hline Indeks Massa Tubuh $\left(\mathrm{kg} / \mathrm{m}^{2}\right)$ & $23.04 \pm 1.71$ & \\
\hline
\end{tabular}

Tabel 2 Hasil uji normalitas data berdasarkan Shapiro-wilk

\begin{tabular}{lcc}
\hline No & Variabel & Nilai $\boldsymbol{p}$ \\
\hline 1 & Leptin & 0,001 \\
2 & SCORAD & 0,622 \\
3 & $\mathrm{pH}$ & 0,003 \\
\hline
\end{tabular}

Signifikan nilai $\mathrm{p}>0,05$

Tabel 3 Korelasi antara kadar leptin dengan SCORAD

\begin{tabular}{lccc} 
& & \multicolumn{2}{c}{ Nilai SCORAD } \\
\cline { 3 - 4 } Korelasi & Jumlah Sampel & Koefisien Korelasi (r) & Nilai P \\
\hline Leptin & 30 & $-0,127$ & $0,043^{*}$ \\
$\mathrm{pH}$ & 30 & 0,810 & $0,001^{*}$ \\
\hline
\end{tabular}

$r$ : koefeisien korelasi uji Spearman Rho, signifikan nilai $p<0.05$

sampel total kurang dari 50. Dari uji tersebut didapatkan bahwa kadar leptin, dan $\mathrm{pH}$ tidak berdistribusi normal, sedangkan SCORAD memiliki distribusi normal, sehingga yang digunakan adalah uji korelasi spearman.
Berdasarkan Tabel 2 didapatkan bahwa data kadar leptin pada semua subjek dermatitis atopik tidak memiliki distribusi yang normal dengan nilai $\mathrm{p}=0,001(\mathrm{p}<0,05)$. Data derajat keparahan dermatitis atopik berdistribusi normal dengan nilai $\mathrm{p}=0,622(\mathrm{p}>0,05)$. Data $\mathrm{pH}$ berdistribusi tidak normal dengan nilai $\mathrm{p}=0,003(\mathrm{p}<0,05)$. (Tabel 2).

Analisis korelasi Spearman's rho digunakan untuk mengetahui korelasi antara kadar leptin dengan SCORAD. Penelitian ini menunjukkan bahwa terdapat korelasi negatif lemah yang bermakna antara leptin dengan SCORAD (r:- 0,127 dan p:0,043), hal ini memberikan gambaran bahwa semakin rendah kadar leptin dalam serum maka akan semakin buruk tingkat keparahan dari dermatitis atopik, disajikan pada (Tabel 3).

Gambaran scattered plot korelasi antara kadar leptin dengan SCORAD disajikan pada Gambar 1 Pada gambar tersebut dapat diketahui bahwa nilai $r$-square memiliki nilai 0,23 yang memiliki arti bahwa leptin mempengaruhi tingkat keparahan dermatitis atopik sebesar 23\% dan masih terdapat $77 \%$ faktor lain selain dari leptin yang mempengaruhi keparahan dari dermatitis atopik (Gambar 1)

Analisis korelasi Spearman"s rho menunjukkan bahwa terdapat korelasi kuat yang bermakna antara pH dengan SCORAD ( $\mathrm{r}: 0,810$ dan $\mathrm{p}:<0,001)$, temuan tersebut memberikan gambaran bahwa semakin tinggi $\mathrm{pH}$ kulit (kondisi $\mathrm{pH}$ semakin basa) maka akan semakin berat tingkat keparahan dari dermatitis atopik yang dialami disajikan pada Tabel 3

Gambaran scattered plot korelasi antara $\mathrm{pH}$ dengan SCORAD disajikan pada Gambar 5.2. melalui grafik tersebut dapat diketahui nilai r-square dalam penelitian ini yaitu 0,695 yang memberikan arti bahwa $\mathrm{pH}$ kulit mempengaruhi keparahan dari dermatitis atopik sebesar 69,5\% dan masih terdapat $31,5 \%$ faktor lain selain dari $\mathrm{pH}$ kulit yang mempengaruhi keparahan dari dermatitis atopic (Gambar 2)

\section{PEMBAHASAN}

Penelitian ini melibatkan 30 subjek penelitian yang memenuhi kriteria inklusi dan eksklusi. Hasil penelitian menunjukkan bahwa kejadian DA lebih banyak pada perempuan $20(66,7 \%)$ dibandingkan dengan laki-laki 10 (33,3\%), dengan perbandingan antara perempuan dan laki-laki adalah $2: 1$. Hasil penelitian ini sesuai dengan penelitian sebelumnya. Penelitian oleh Vina dkk di RSUP Sanglah Denpasar didapatkan dermatitis DA lebih banyak terjadi pada perempuan 15 orang $(57,7 \%)$ dibandingkan laki laki yaitu 11 orang $(42,3 \%)$, dengan perbandingan antara perempuan dan laki-laki 


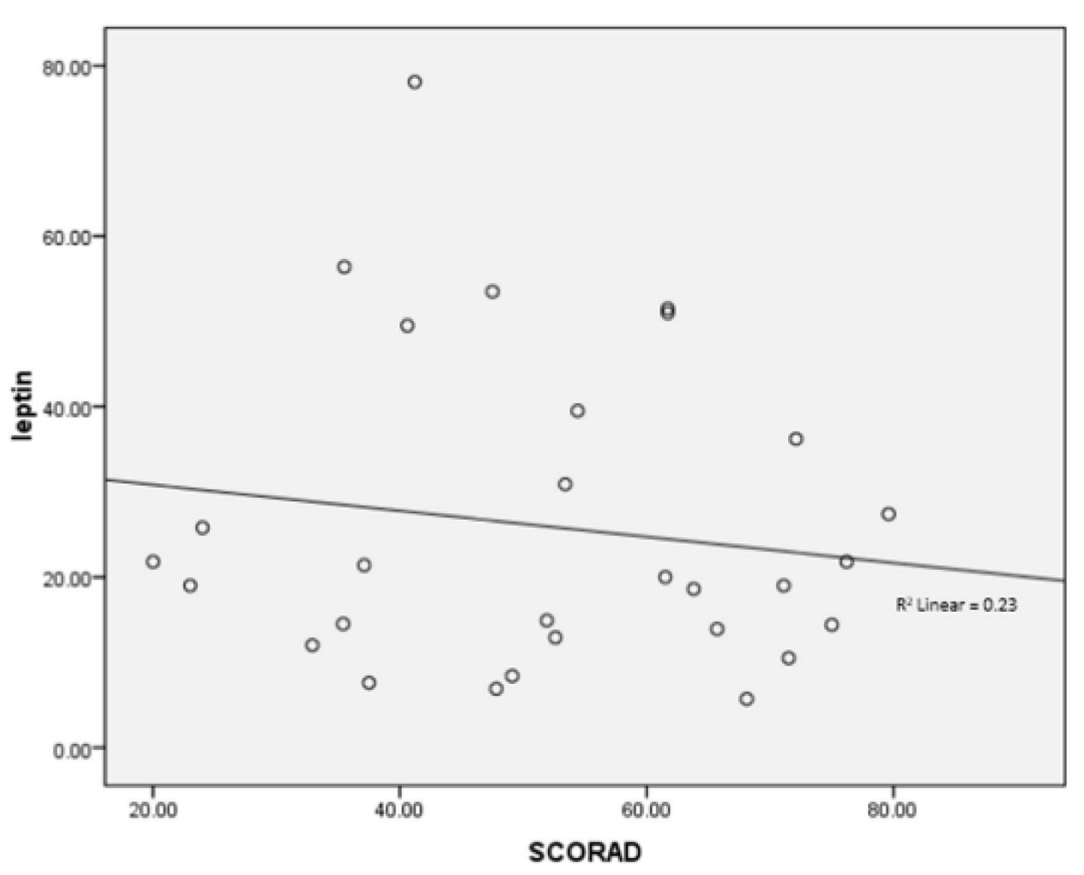

Gambar 1 Grafik scattered plot antara kadar leptin dengan SCORAD

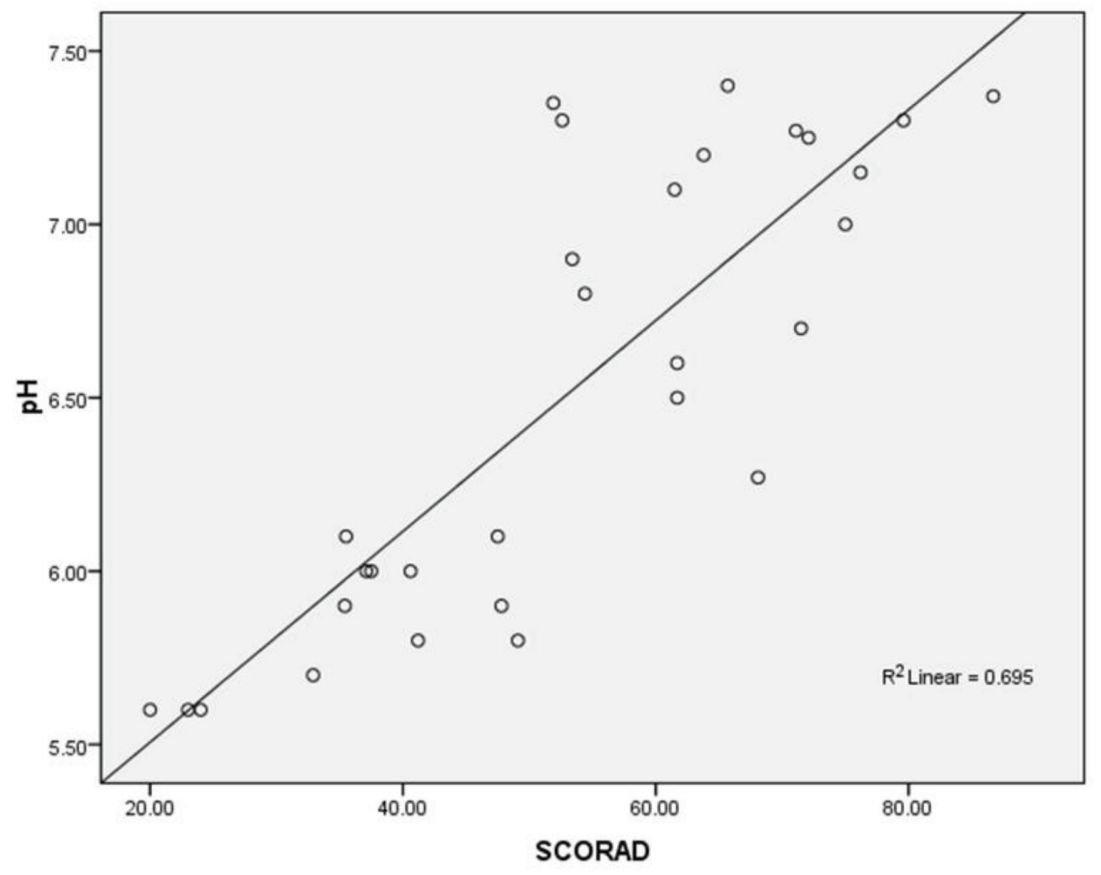

Gambar 2 Grafik scattered plot antara pH dengan SCORAD

adalah $1,4: 1 .^{12}$ Sedangkan studi yang dilakukan oleh Maymi dkk di Puerto rico juga menunjukkan bahwa pasien DA pada perempuan sebanyak 288 orang, lebih banyak dibandingkan dengan DA laki-laki yaitu didapatkan 232 orang. ${ }^{13}$ Dengan demikian, hasil penelitian serupa dengan beberapa hasil penelitian terdahulu sehingga menunjukkan kejadian DA pada perempuan lebih banyak dibandingkan laki-laki dengan perbandingan 1,5: 1 . Tidak ada predisposisi genetik pada perempuan untuk lebih rentan terjadi DA. ${ }^{3}$
Penelitian ini memberikan hasil bahwa kadar leptin berkorelasi negatif dengan tingkat keparahan DA (SCORAD), yang berarti terdapat korelasi negatif antara kadar leptin dengan tingkat keparahan DA. Leptin sendiri secara umum berperan dalam mengatur keseimbangan massa jaringan adipose dalam tubuh melalui respon secara sentral melalui rangsangan pada hipotalamus untuk meningkatkan atau menurunkan asupan makanan dan meningkatkan atau menurunkan penggunaan energi. Kerja leptin secara perifer adalah melalui ikatan leptin dengan reseptor yang terdapat pada beberapa organ tubuh termasuk kulit. ${ }^{8}$ Adanya ikatan leptin dan reseptornya di kulit dapat memicu proliferasi serta diferensiasi sel-sel keratinosit dan fibroblast, serta supresi produksi sitokin Th2 dan peningkatan sekresi sitokin Th1b yang menyebabkan adanya ketidak seimbangan dari Th1 terhadap Th2 yang kemudian disertai dengan peningkatan sekresi sitokin, seperti IL-3, IL-4, IL-5, IL-6, IL-10 dan IL-13. Interleukin 4, IL-5 dan IL-13 yang kemudian menyebabkan maturasi dari limfosit B menjadi sel plasma yang kemudian akan meningkatkan prduksi dari level Ig E dan eosinofil serta menginduksi molekul adesi yang terlibat pada migrasi sel inflamasi ke lesi kulit, sehingga timbul DA. ${ }^{8}$ Terdapat beberapa penelitian yang menghubungkan nilai kadar leptin dengan derajat keparahan DA (SCORAD). Penelitian oleh Nicola Balato menunjukkan terdapat korelasi negatif sedang antara kadar leptin dengan limfosit $\mathrm{T}\left(\mathrm{CD} 4{ }^{+} \mathrm{CD} 25^{+}\right) .{ }^{14} \mathrm{Hal}$ tersebut secara langsung berdampak pada kesimbangan dari Th1 dan Th2 yang kemudian akan kembali mencetuskan persistensi dari DA. Penelitian oleh Sung Chul Seo menunjukkan terdapat korelasi negatiflemah antara kadar leptin dengan keparahan DA yang dikaji menggunakan penilaian SCORAD pada pasien dermatitis atopik..$^{15}$ Penelitian oleh Nagel G dkk menunjukkan bahwa kadar adiponektin yang rendah dikaitkan dengan peningkatan dari gejala DA yang lebih parah, dimana orang dengan kadar adiponektin yang rendah memiliki risiko 3,23 kali lebih besar untuk meningkatkan keparahan DA dibandingkan dengan orang yang memiliki kadar adiponektin serum yang normal. ${ }^{16}$ Adiponektin merupakan varian biomarker yang serupa dengan leptin dimana merupakan hasil sekresi dari sel adiposit dalam jaringan lemak dan memiliki peran yang sama dalam memodulasi sistem imun berbarengan dengan leptin. Jumlah sampel pada kelompok yang memiliki tingkat keparahan (SCORAD) berat lebih banyak dibandingkan dengan kelompok yang memiliki tingkat keparahan (SCORAD) ringan dan kelompok yang memiliki tingkat keparahan (SCORAD) sedang.

Pada penelitian ini nilai $\mathrm{pH}$ kulit dengan derajat keparahan DA berdasarkan indeks SCORAD 
dilakukan dengan uji spearman. Didapatkan hasil korelasi kuat bermakna anatara $\mathrm{pH}$ kulit dengan SCORAD (r: 0,810 dan p: <0,001). Penelitian yang dilakukan oleh Knor dkk untuk mengetahui nilai $\mathrm{pH}$ kulit dan hidrasi stratum korneum menunjukkan $\mathrm{pH}$ kulit didapatkan lebih rendah signifikan pada kelompok sehat dibandingkan kulit tanpa lesi pada pasien DA $(\mathrm{P}<0.05) .{ }^{17}$

Tingkat asam-basa kulit yang dikenal dengan istilah $\mathrm{pH}$ memiliki beberapa fungsi mekanisme pertahanan terhadap masuknya mikroorganisme seperti menurunkan kolonisasi bakteri patogen, dan mendukung adhesi bakteri nonpatogen pada kulit. $\mathrm{pH}$ berfungsi menjaga keseimbangan dan permeabilitas sawar kulit, mempengaruhi deskuamasi stratum korneum, dan menjaga integritas serta kohesi stratum korneum. ${ }^{18}$ Hal yang berperan pada peningkatan $\mathrm{pH}$ pada pasien DA yaitu pengurangan sekresi sebum dan maturasi lipid startum korneum, penguarangan pembentukan dan meningkatnya degradasi filagrin, serta pengurangan sekresi badan oldland yang merupakan sumber proton. ${ }^{18}$ Kelainan filagrin pada pasien DA menunjukkan adanya kelainan fungsi sawar kulit yang ditandai dengan peningkatan TEWL, peningkatan $\mathrm{pH}$ kulit, dan perubahan ekspresi seramid pada stratum korneum. ${ }^{19}$

Ada ukuran khusus antara pasien DA dengan orang normal, bahkan pada kulit yang terlihat normal atau tanpa lesi. ${ }^{20}$ Tanda klinis kulit kering adalah salah satu tanda pasien DA dan menunjukkan peningkatan TEWL (Trans Epidermal Water Loss). ${ }^{21}$ Elias menyatakan peningkatan TEWL berhubungan dengan kenaikan $\mathrm{pH}$, hidrasi yang rendah, dan penurunan kandungan lipid yang berada di permukaan kulit. Penelitian - penelitian tersebut menunjukkan adanya hubungan yang kuat antara mutasi filagrin dengan DA. Pada pasien DA kelainan filagrin menujukkan terdapat kelainan fungsi sawar kulit yang ditandai dengan peningkatan TEWL, peningkatan $\mathrm{pH}$ kulit, dan perubahan ekspresi seramid pada stratum korneum. ${ }^{22}$

Patogenesis DA dipengaruhi salah satunya oleh $\mathrm{pH}$. Keberhasilan pengobatan DA memerlukan pendekatan sistemik dan mencakup berbagai sisi yaitu hidrasi kulit, terapi farmakologikal dan identifikasi serta eliminasi faktor pencetus kekambuhan, misalnya bahan-bahan yang bersifat iritan, alergen, agen infeksius dan stresor emosional. Pilihan terapi untuk DA yang berhubungan dengan fungsi sawar kulit dan menjaga fungsinya. Perbaikan sawar kulit lebih lanjut akan memperbaiki kondisi kulit secara keseluruhan, dan akan mempengaruhi keadaan fisiologis kulit termasuk kelembaban kulit dan $\mathrm{pH}^{3}$ Untuk mengurangi kekambuhan pasien DA maka sebaiknya memakai produk pembersih berupa sabun dengan $\mathrm{pH}$ seimbang dan memakai emolien terutama yang bersifat memperbaiki sawar kulit yang dapat menjaga nilai pH kulit yang optimal.

\section{SIMPULAN}

Pada hasil penelitian ini menunjukkan bahwa terdapat korelasi negatif lemah antara leptin serum dengan tingkat keparahan dermatitis atopik. Sedangkan terdapat hasil korelasi kuat bermakna antara $\mathrm{pH}$ kulit dengan nilai SCORAD.

\section{DAFTAR PUSTAKA}

1. Bieber T, Bussmann C. Atopic Dermatitis. In: Bolognia JL, Jorizzo JL, Schaffer JV, editors. Dermatology. $3^{\text {th }}$ Ed. Elsevier Saunders. 2012: 203-218.

2. Leung DY. Atopic Dermatitis: New Insights and Opportunities for Therapeutic Intervention. J Allergy Clin Immunol. 2000; 105(5):860-76.

3. Leung DY, Lawrence FE, Boguniewics M. Atopic Dermatitis (Atopic Eczema). In: Goldsmith LA, Katz SI, Gilchrest BA, Paller AS, Leffell DJ, Wolff K, editors. Fitzpatrick's Dermatology in General Medicine. $8^{\text {th }}$ ed. New York: McGraw Hill. 2012: 165-82.

4. Rubel D, Thirumoorthy T, Soebaryo RW, Weng SCK, Gabriel TM, Villafuerte LL et al. Consensus Guidelines for The Management of Atopic Dermatitis: An Asia-Pacific Perspective. J Dermatol, 2013; 40(3):160-71.

5. Wardhana M, Suryawati N, Ariana. The effect of psychological stress on C-reactive protein and peripheral blood cells count in chronic idiopathic urticaria. Bali Medical Journal. 2017; 6(1):198-203

6. Wauman J, Zabeau L, Tavernier J. The Leptin Receptors Complex: Heavier than Expected. Front Endocrinol. 2017; 8(30):1-20.

7. Mantzoros CS, Magkos F, Brinkoetter $\mathrm{N}$ et al. Leptin in Human Physiology and Pathophysiology. Am J Physiol Endocrinol Metab. 2011; 301(4):567-84.

8. Kelesidis T, Kelesidis I, Chou S, Mantzoros CS. Narrative review: the role of leptin in human physiology: emerging clinical applications. Ann Intern Med. 2010;152(2):93-100

9. Liu W, Zeng Q, Zhou L, Luo R, Dong H. Association of Leptin with Disease Severity and Inflammation Indicators in Chinese Obese Childrn with Allergic Rhinitis. Peidatric Allergy Immunol. 2018; 29(2):186-193.

10. Mohamed SA, Alsayad T, El-Askary A, Alwata HA. Serum Leptin Level among School Children with Atopic Dermatitis. Neonatal Pediatric Med. 2017; 3(2);1-6.

11. Seo S, Won SY, Cho Y, Park SH, Choung JT, Yoo Y. Leptin and Atopic Dermatitis in Korean Elementary School Children. Iran J Allergy Asthma Immunol. 2016; 15(2):138-144.

12. Vina GA. Kadar Serum Leptin Yang Tinggi Merupakan Faktor Risiko Terjadinya Dermatitis Atopik" [Tesis]. Universitas Udayana. 2018

13. Maymí MA, Somolinos AL, Nazario CM, Sánchez JL. The prevalence of atopic dermatitis in Puerto Rican schoolchildren. P R Health Sci J. 2007; 26(2):127-33.

14. Balato N, Nino M, Patruno C, Matarese G, Ayala F. "Eczemas" and leptin. Dermatitis. 2011; 22(6):320-3.

15. Seo SC, Yoon WS, Cho Y et al. Leptin and Atopic Dermatitis in Korean Elementary School Children. Iran J Allergy Asthma Immunol. 2016; 15(2):138-144

16. Nagel G, Koenig W, Rapp K, Wabitsch M, Zoellner I, Weiland SK. Associations of adipokines with asthma, rhinoconjunctivitis, and eczema in German schoolchildren. Pediatr Allergy Immunol. 2009; 20(1):81-8. 
17. Knor T, Meholjić-Fetahović A, Mehmedagić A. Stratum corneum hydration and skin surface $\mathrm{pH}$ in patients with atopic dermatitis. Acta Dermatovenerol Croat. 2011; 19(4):242-7.

18. Rippke F, Schreiner V, Doering T, Maibach HI. Stratum corneum $\mathrm{pH}$ in atopic dermatitis: impact on skin barrier function and colonization with Staphylococcus Aureus. Am J Clin Dermatol. 2004; 5(4):217-23.

19. von Gunten S, Marsland BJ, von Garnier C, Simon D. Update in clinical allergy and immunology. Allergy. 2012; 67(12):1491-500

20. Kubo A, Nagao K, Amagai M. Epidermal Barrier Dysfunction and Cutaneus in Atopic Dermatitis. J Clin Invest. 2012; 113(5):651-57.
21. Elias PM, Hachem JP, Crumrine D, Fluhr J, Brown BE, Feingold KR. pH Directly Regulates Epidermal Permeability Barrier Homeostasis, and Stratum Corneum Integrity/Cohesion. J Invest Dermatol. 2003; 125: 510-20.

22. Boguniewicz M, Leung DYM. Atopic Dermatitis: A Disease of Altered Skin Barrier and Immune Dysregulation. Immunol Rev. 2011; 242(1):233-246.

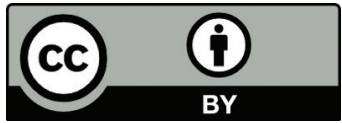

This work is licensed under a Creative Commons Attribution 